Akdeniz Eğitim Araştırmaları Dergisi

Mediterranean Journal of Educational Research 2020, Cilt 14 Say1 32, Sayfa 116-135

https://doi.org/10.29329/mjer.2020.258.7

Copyright (C) 2020. Açık Erişim Makale CC BY-NC-ND

\title{
Argumentation Practice in the Context of Nuclear Power Plants
}

\author{
Eylem Yalçınkaya Önder ${ }^{1}$, \& Esin Pekmez ${ }^{2}$
}

\begin{abstract}
This study explored pre-service science teachers' argument quality in the context of nuclear power plants. 48 pre-service science teachers in a public university consisted of the study group of the study. The argument qualities of pre-service teachers who trained about argumentation including the Toulmin Argument Pattern (TAP) were examined. In this study, holistic single case study design, one of the qualitative research methods, was used. The data of the study were collected through both written and verbal arguments. The written and verbal argument analysis indicated that teacher candidates lacked of competency in developing scientific arguments in the context of nuclear power plants. In addition, it has been found that teacher candidates have various alternative conceptions about nuclear power plants. In general, it is striking that the quality of the arguments written in the relevant literature is quite poor. For this reason, it is important to add to the literature the studies in which written arguments are supported with verbal arguments.
\end{abstract}

Keywords:Pre-Service Teachers, Argumentation, Socio-Scientific Issue, Written Arguments, Verbal Arguments

Geliş Tarihi: 06.01.2020 - Kabul Tarihi: 17.06.2020 - Yayın Tarihi: 29.06.2020

DOI: $10.29329 /$ mjer.2020.258.7

\section{Nükleer Santraller Konusunda Argümantasyon Uygulaması}

Özet: Bu çalışmanın amacı fen bilgisi öğretmenliğinde okuyan öğretmen adaylarının nükleer enerji konusundaki argüman kalitesini incelemektedir. Araştırmanın çalışma grubunu bir devlet üniversitesinde öğrenim gören 48 fen bilgisi öğretmeni oluşturmaktadır. Bu çalışmada nitel araştırma yöntemlerinden bütüncül tek durum deseni kullanılmıştır. Toulmin Argüman Modelini içeren ve argümantasyon konusunda eğitim alan öğretmen adaylarının argüman nitelikleri incelenmiştir. Çalışmanın verileri hem yazılı hem de sözlü argümanlar yoluyla toplanmıştır. Yazılı ve sözlü argümanların analizi, öğretmen adaylarının nükleer santraller konusunda bilimsel tartı̧̧malar geliştirme yetkinliklerinin yeterli olmadığını göstermiştir. Ayrıca, bu çalışmada öğretmen adaylarının nükleer santraller hakkında çeşitli alternatif fikirlere (kavram yanılgılarına) sahip oldukları bulunmuştur. Genel olarak, ilgili literatürde öğrencilerin yazılı argümanlarının kalitesinin zayıf olduğu belirtilmektedir. Bu nedenle, yazılı argümanların sözlü argümanlar ile desteklendiği çalışmaları literatüre eklemek önemlidir.

Anahtar kelimeler: Öğretmen Adayları, Argümantasyon, Argüman, Bilimsel Tartışma, Sosyo-Bilimsel Konu, Yazılı Tartı̧̧ma, Sözlü Tartışma.

\footnotetext{
${ }^{1}$ Eylem Yalçınkaya Önder, Assist. Prof., Fen Bilgisi Eğitimi Abd, Çanakkale Onsekiz Mart Üniversitesi, ORCID: 0000-
} 0003-1306-9931

Correspondence: eylemyk@gmail.com

${ }^{2}$ Esin Pekmez, Assoc. Prof. Dr., Science Education, Ege University, ORCID: 0000-0001-5213-9010 


\section{INTRODUCTION}

Berland and McNeill (2009, p.1) define argumentation as 'a central goal of science education because it can engage students in a complex scientific practice in which they construct and justify knowledge claims'. Studies reported that students face difficulties in constructing scientific explanations (Sandoval \& Millwood, 2005). Hsu et al. (2015, p.48) summarized the common difficulties that students face in constructing scientific explanations as 'failing to cite sufficient and appropriate evidence for their claims, failing to connect evidence to appropriate scientific principles, and not clearly interpreting their inferences and articulating relationships between evidence and claims'. Many researchers claim that science classes should include discourse that facilitates students' practice of argumentation (Sandoval \& Millwood, 2005). Driver, Newton, and Osborne (2000) stated that argumentation-focused teaching activities improves students' conceptual abilities and research abilities, and facilitates their understanding of the scientific epistemology. However, they pointed out that current classroom practices give young people very little opportunity to improve their argumentation skills, and also teachers' inadequacy of pedagogical skills in creating an argumentationbased environment in the classroom was a major impediment to progress in this area.

$\mathrm{Wu}$ and Hsieh (2006) mentioned that students tend to produce inconsistent explanations from personal thoughts and that they cannot establish logical connections between arguments and claims in their explanations. The concept of argumentation has been explored in various ways with different approaches such as instructional strategies adopted by science teachers for their argumentation-based science teaching (Duschl \& Osborne, 2002; Erduran, Simon, \& Osborne, 2004; Uluçınar-Sağır \& Kılıç, 2013; Kaya, 2013; Zohar \& Nemet, 2002). All of them points to the importance of argumentation in science education.

According to the studies on argumentation, even middle school and high school students seem to lack the high level of argumentation elements such as warrants and backing (Sandoval \& Millwood, 2005). Muratsua et al. (2015) draw attention to that few numbers of studies was conducted to identify students' understanding of the criteria for quality of rebuttals before training about argumentation. Martín-Gámez and Erduran (2018) noted that pre-service science teachers have difficulty in understanding arguments, for instance; they did not understand the role and meaning of the warrants in scientific arguments and were limited to discussions, open debates and experiments on the use of different strategies. Moreover, it was found that the participants' age range and length of teaching experience had no influence on the quality of their understanding of argumentation. They also expressed that pre-service teachers are more likely to benefit if they participate in more robust and lengthy sessions on argumentation.

There are various studies on the use of written arguments in science education, but it is noteworthy that the number of verbal arguments is quite limited compared to written arguments. In 
this sense, this study, in which both written and verbal arguments are used, would contribute to the related literature. The main purpose of this study was to identify pre-service science teachers' argument quality and determine the frequency of using the elements in Toulmin Argument Model (TAP) in the context of nuclear power plants. The targeted population is the pre-service teachers who enrolled in a science education program.

\section{Argumentation in Science Education}

Argumentation has different definitions in science education. Argumentation 'is a central means by which the community assesses the promise of conjectures and validity of claims' (Berland \& Hammer, 2012, p.68). It is defined by Toulmin (1958) as the 'the processes of justification of claims with evidence'. Toulmin (1958) stated that argumentation is an important part of the reasoning process both in daily life and in science. He suggested an argument model to make the concept of the argument more concrete and understandable. There are six items in this model. These are; data, claim, warrant, backing, and rebuttal. Toulmin defines the claim as an assertion put forward publicly for general acceptance, data as the specific facts relied on to support a given claim, backings as generalizations making explicit the body of experience relied on to establish the trustworthiness of the ways of arguing applied in any particular case, rebuttals as the extraordinary or exceptional circumstances that might undermine the force of the supporting arguments. Toulmin further considers the role of qualifiers as phrases that show what kind of degree of reliance is to be placed on the conclusions, given the arguments available to support them. On the other hand, TAP is criticized by Nussbaum (2011) since it does not adequately explain the dynamics of the epistemic and social criteria of the argumentation. Zembal-Saul et al. (2002) stated that arguments constructed by pre-service teachers lacked complexity and exhibited limitations regarding the nature and use of evidence.

An argumentation-based intervention leads to a better acquisition of concepts related to the rate of reaction (Cetin, 2014). A study by Aydeniz et al. (2012) with university students showed that the argumentation-based teaching method has a positive effect on students' the conceptual understanding of gas properties and gas behavior. There has been a growing interest to argumentation based teaching in science education (e.g., Çınar \& Bayraktar, 2014; Venville \& Dawson, 2010; von Aufschnaiter et al., 2008; Osborne \& Simon, 2008; Özdem et al., 2013; Zohar \& Nemet, 2002). Venville and Dawson (2010) stated that explicit instruction on argumentation promotes students' conceptual understanding of genetics topic. As Cetin et al. (2016) declared that the socio-scientific issues movement has come to the forefront in science courses in recent years. Student engagement in scientific argumentation can foster a better understanding of the concepts (Sampson \& Blanchard, 2012). The limited number of argumentation in science classes requires the development of science teachers' argumentation skills (Martín-Gámez \& Erduran, 2018). This study aimed to contribute to the relatively limited literature on the argumentation of pre-service science teachers in the context of nuclear power plants, one of the socio-scientific issues. 


\section{METHOD}

\section{Research Design}

As in this study, some research problems require explanatory, in-depth and detailed information rather than general findings. At this stage, educational researchers need different methods. Qualitative research methods provide educational researchers with important starting points in studying such research problems that require in-depth and detailed knowledge (Yıldırım, 1999). Case studies are studies in which an individual, a group, an environment or a process can be explored to find answers to questions such as how, what and why, and in learning various subjects of education (Yildırım \& Şimşek, 2011). In this research, holistic single case study design, one of the qualitative research methods, was used to reveal pre-service students' ideas about nuclear power plants.

The study group consisted of 48 pre-service teachers studying at Science Teacher Education program in a public university. This study was carried out with an already formed group of pre-service students attending their formal education. Therefore, convenience sampling technique was used as a non-random sampling method for forming the study group. Even though necessary permissions have been taken from the institution where the study was conducted, the students voluntarily participated in this research.

\section{Research Instrumentations and Procedures}

This study, which is the part of a long-term scientific research supported by the Scientific and Technological Research Council of Turkey (TUBITAK) 2218 Domestic Postgraduate Scholarship Program, aimed to teach the method of argumentation-based instruction to pre-service teachers and to determine frequency of using the elements in Toulmin Argument Model through activities involving socio-scientific issues and science concepts. In the scope of this project, six activities were prepared to be used during one education period. The analysis of data on nuclear power plants which is one of these six activities was presented in detail in this study. In addition, though the data about nuclear power plants was presented as a poster at EJER 2017 congress, it was not published as a full text anywhere except for the current study.

The study group of this study had not received a course or training about argumentation in their formal education program earlier to present study. Before tutoring, candidates were asked to create groups of students randomly and a debate was initiated by asking students whether they supported the establishment of nuclear power plants in their country or in the city they live in. Additionally, some questions about which the desired scientific answers were not received in a similar study by Aydeniz and Gürçay (2013) were also asked. In-group and inter-group discussions were videotaped for analysis. After then, they were trained by one of the researchers of the study for two and half hours about argumentation and the Toulmin Argument Pattern (TAP). During education, scientific definitions from literature on arguments and argumentation concepts were shared with pre-service 
teachers. The training given to teachers also included TAP and its six elements. Moreover, argument examples from literature on various subjects were presented in the language of the students and the features that should be in a good argument were also emphasized. Upon training about argumentation, the same activity was repeated considering the elements of this model. Throughout the activity, preservice teachers found an opportunity to engage in groups and exchange ideas with one another.

\section{Data Analysis}

The opinions of group students were received in written first and these ideas were shared mostly through group spoken. Researcher of the study tried to create a scientific discussion environment in the class by asking probing questions to them so as to express their arguments verbally. The written arguments of the students were taken on a group basis, and the verbal arguments were also videotaped. The data of this study were transcribed and analyzed by a researcher of the study. It was determined that the arguments of students about the subject of nuclear power plants were classified according to the elements in Toulmin Argument Model such as data, warrant, and backing. Before and after the training of the students about argumentation, changes in the use of elements in the Toulmin argument model were examined on a group basis and presented in the results section of the current study.

\section{RESULTS}

\section{Case}

A nuclear power plant consisting of one or more nuclear reactors is a facility where electrical energy is generated using radioactive materials as fuel. Due to the use of radioactive materials, it involves different and more stringent security measures than those of other power plants in the technology (quoted from Wikipedia).

- Students were asked whether they support the establishment of nuclear power plants in the country or in the city they live in.

- Students were asked whether nuclear power plants release harmful gases to human and animal health into the air.

- $\quad$ Students were asked whether the radiation can cause mutation in human genes.

\section{Analytical framework to assess the quality and complexity of argumentation}

\section{Written and Verbal Argument Analysis for Group A}

In the Figures below, you can see the numerical values of the elements used in the TAP. Figure 1 and 2 indicated that there are no striking changes in the analysis of written and verbal arguments in terms of the elements used in the TAP. 

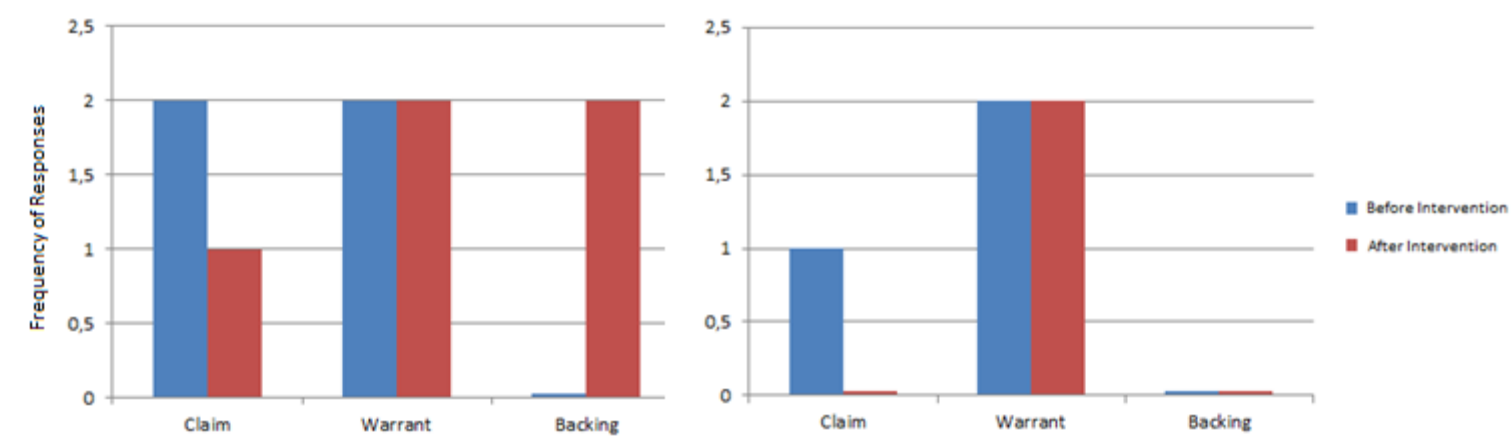

Figure 1. Written Argument Analysis for Group A Figure 2. Verbal Argument Analysis for Group A

The following Table 1 presents a written and verbal argument analysis of the elements that fit the elements of TAP for Group A. When Table 1 was examined, it has been concluded that, students do not support the establishment of nuclear power plants in their country both before and after intervention. They argue that the necessary security precautions would not be taken sufficiently in the country they live in. They also believed in that radioactive energy would harm the nature and the living creatures unless the necessary measures are not taken.

Table 1. Analysis of written and verbal arguments for Group A

\begin{tabular}{|c|c|c|}
\hline Argument & Before Intervention & After Intervention \\
\hline Written & \multicolumn{2}{|l|}{ Supportive Comments/Pro- } \\
\hline Argument & $\begin{array}{l}\text { Arguments } \\
\text { Claim: Energy concerns the future } \\
\text { of a country and energy needs are } \\
\text { increasing day by day. } \\
\text { Claim: We need a constant and }\end{array}$ & $\begin{array}{l}\text { Warrant(s): There is no security culture in } \\
\text { our country. This topic is probably not } \\
\text { given enough attention. In a country where } \\
\text { even natural phenomena have caused } \\
\text { considerable damage; nuclear power plants } \\
\text { are in constant danger of accidents. }\end{array}$ \\
\hline & power plants can be supported. & \multirow{2}{*}{$\begin{array}{l}\text { Claim: We think that } \\
\text { security measures will } \\
\text { not be given enough } \\
\text { attention. }\end{array}$} \\
\hline & $\begin{array}{l}\text { Unsupportive Comments } \\
\text { Warrant: Nuclear power plants }\end{array}$ & \\
\hline & $\begin{array}{l}\text { other power plants and I think that } \\
\text { these measures will not be taken } \\
\text { sufficiently. } \\
\text { Warrant: Radioactive energy harms } \\
\text { nature and living things. More } \\
\text { renewable energy productions such } \\
\text { as water and wind energies should }\end{array}$ & $\begin{array}{l}\text { Backing(s): There are some problems even in countries } \\
\text { with sufficient training on this issue, we do think that } \\
\text { enough attention will not be given to this issue in our } \\
\text { country. Consumption can be reduced instead of } \\
\text { increasing production because the wastes during the } \\
\text { operation of nuclear power plants are toxic and cancerous. }\end{array}$ \\
\hline
\end{tabular}




\begin{tabular}{lll}
\hline $\begin{array}{l}\text { Verbal } \\
\text { Argument }\end{array}$ & $\begin{array}{l}\text { We actually do not fully support or } \\
\text { not support it. There are reasons for } \\
\text { supporting and not supporting the } \\
\text { establishment of nuclear power } \\
\text { plants. }\end{array}$ & $\begin{array}{l}\text { Warrant(s): We think that security measures will not be given } \\
\text { enough importance in our country. As a qualifier, there is no } \\
\text { security culture in our country; probably not enough attention is } \\
\text { given to this issue. In this country where even natural phenomena } \\
\text { are causing considerable damage, nuclear power plants are in } \\
\text { constant danger of accidents. }\end{array}$ \\
& Warrant(s): The reason for our \\
support is that nuclear plants need \\
more security measures than other \\
power plants and we think that \\
these security precautions will not \\
be taken sufficiently in this country. \\
Therefore, radioactive energy \\
harms the nature and the living \\
creatures. We think that more \\
importance should be given to \\
natural energy productions like \\
wind energy. \\
Do nuclear power plants release \\
harmful gases to human and animal \\
health into the air? \\
Claim: If no measures are taken, it \\
will be released.
\end{tabular}

\section{Written and Verbal Argument Analysis for Group B}

In the analysis of the verbal arguments of Group B, there was an improvement in the frequency of the elements used in the TAP.
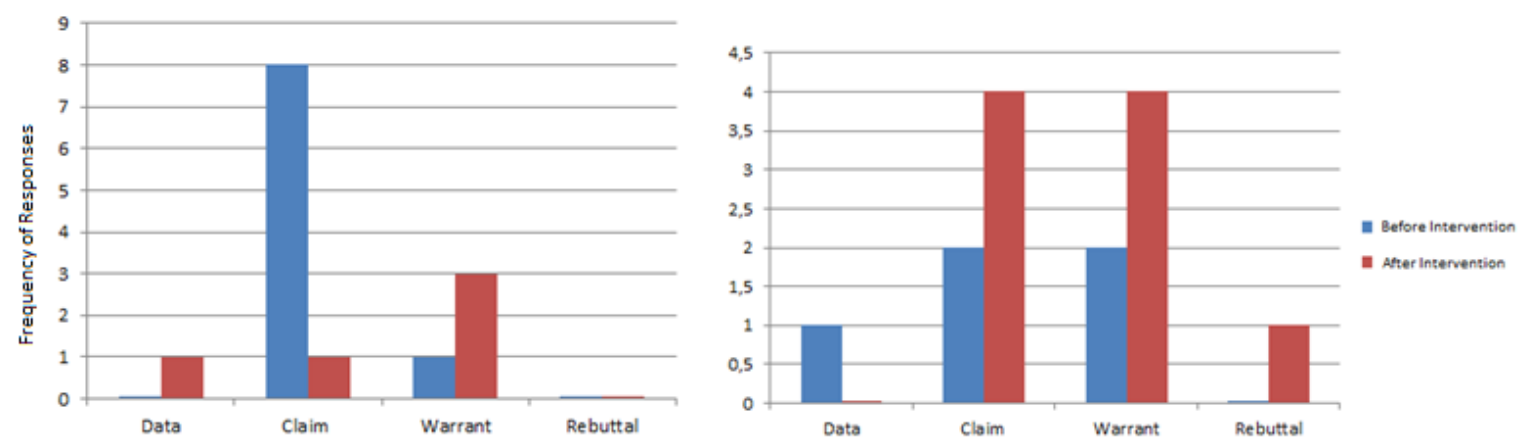

Figure 3. Written Argument Analysis for Group B Figure 4. Verbal Argument Analysis for Group B

The following Table 2 presents a written and verbal argument analysis of the elements that fit the elements of TAP for Group B. As can be seen in Table 2, it was observed that there are also students who support the establishment of a nuclear power plants in the country or city where they live as well as those who do not. The reasons for the supporters were that nuclear power plants meet this energy requirement and provide job opportunities to many people. Those who do not support the establishment of a nuclear power plants claimed that they creates environmental pollution, affects living creatures adversely, harms the ecosystem, damages the ozone layer, triggers global warming, 
increase disease rates but they could not provide a scientific justification for how they would occur. Moreover, students mostly gave examples from Chernobyl accident, Hiroshima and Nagasaki attack. The frequent use of giving examples about these disasters reveals that these events had deep impact on people's memory. In addition, they also claimed that nuclear power plants are harmful to the environment and even emits harmful gases to the air.

Table 2. Analysis of written and verbal arguments for Group B

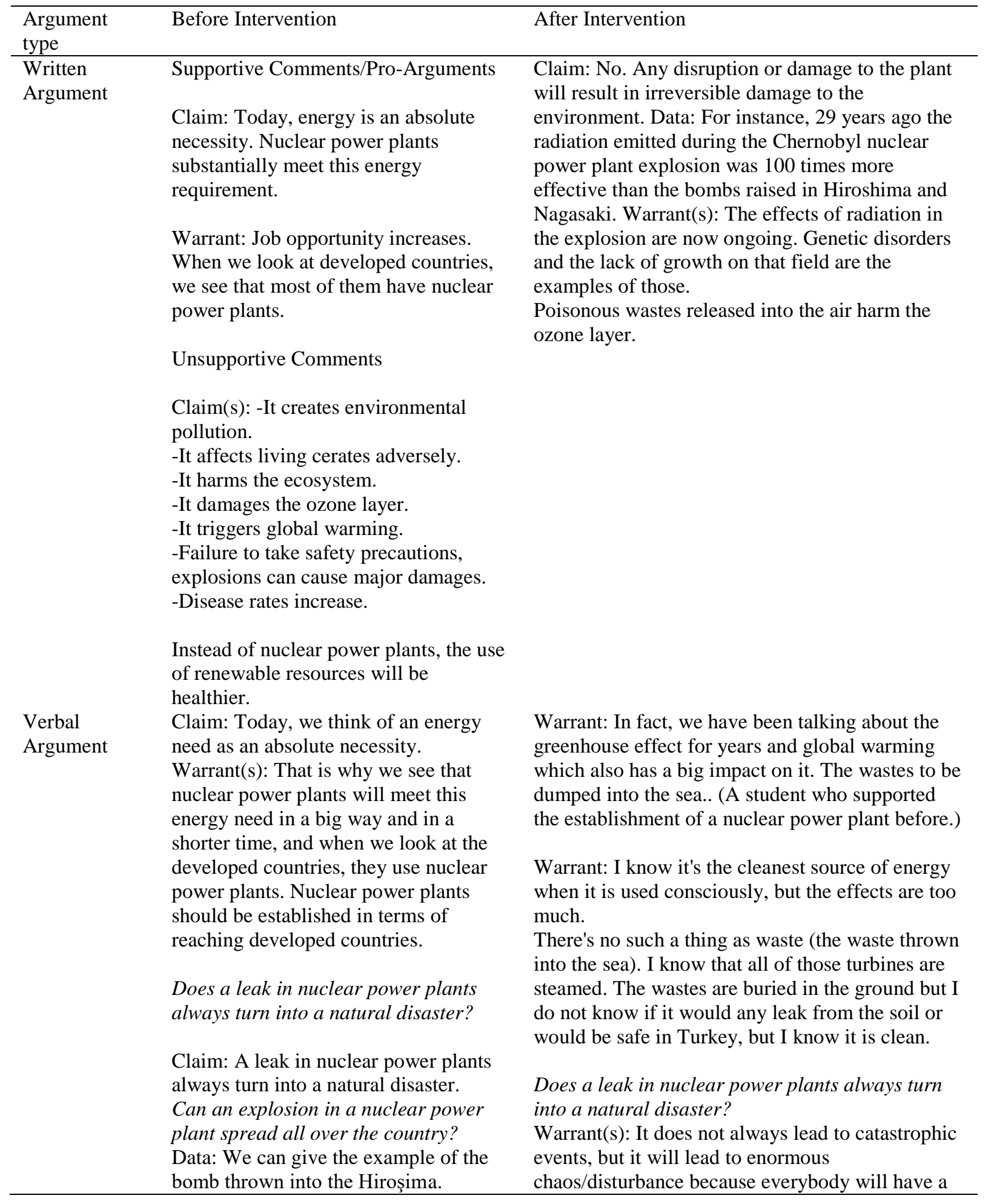


fear that it would spread. Then, all energy production would be ceased. The whole plant would need to be taken under control and the plant would have to be scanned to the finest detail to find out what the source of the problem is. All of this would cause both material and public problems.

Can radiation cause mutation in human genes? Claim: It could be due to radiation, it's already affecting the human body ...

Claim: It corrupts our DNA.

Do the other pollutants get damage to the DNA? Claim: Its effect is probably more.

Claim: Since it's radiation, radiation corrupts our DNA and disturbs us.. irreversibly...

Your friends said that nuclear power plants release various gases into the air. Do you think that nuclear power plants release harmful gases into the air to human and animal health?

Rebuttal: In an article I read, it was written that the wastes from the use of nuclear energy are even less harmful than the sun, but its use must be $100 \%$ perfect. I read in the article that if there was no any problem, it would be even less harmful to the sun when it works perfectly.

Warrant(s): Even if it is not a catastrophic disaster, the release of harmful gases is already certain because there was not a leak in Hiroshima in Japan but a great disaster, but there has not been any weed there for years. Such a thing can only be due to the gases. Something that can affect the soil, something that can affect it, is already gas.

\section{Written and Verbal Argument Analysis for Group C}

As seen Figures 5 and 6, comments on the variation of the frequency of the elements used in the TAP cannot be applicable due to the absence of students after practice.
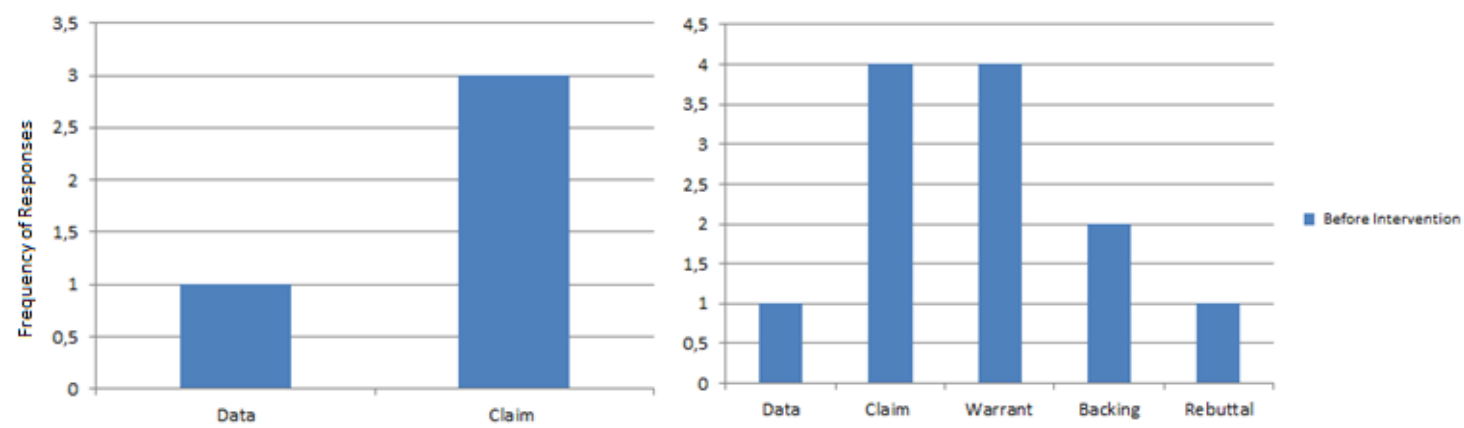

Figure 5. Written Argument Analysis for Group C

Figure 6. Verbal Argument Analysis for Group C 
Similar to other group of students, students claimed that radiation can cause mutations in human genes and the mutations cause genetic disorders, children with disabilities, children with mental disabilities, physical disorders. However, they could not make a scientific explanation of how the mutations can take place. They claimed that nuclear wastes would harm the environment, nature and also animals as an adverse effect.

Table 3. Analysis of written and verbal arguments for Group C

\begin{tabular}{|c|c|c|}
\hline Argument type & Before Intervention & After Intervention \\
\hline \multirow{5}{*}{$\begin{array}{l}\text { Written } \\
\text { Argument }\end{array}$} & Supportive Comments/Pro-Arguments & Group students did not exist in class. \\
\hline & No. & \\
\hline & Unsupportive Comments & \\
\hline & $\begin{array}{l}\text { Claim: It harms nature by causing air } \\
\text { pollution. }\end{array}$ & \\
\hline & $\begin{array}{l}\text { Warrant(s):-Nuclear plant wastes lead to } \\
\text { soil pollution because they are not } \\
\text { readily soluble in the environment. They } \\
\text { damage trees. Thus, oxygen production } \\
\text { reduces and quality of life reduces. } \\
\text {-Despite strict safety precautions, } \\
\text { radiation to spread in the event of a } \\
\text { slight leak that may occur as a result of } \\
\text { natural disasters causes genetic disorders } \\
\text { in the long term. } \\
\text {-It is also very risky to dismantle the } \\
\text { plants that have completed their lives } \\
\text { because they are long and costly to } \\
\text { install. }\end{array}$ & \\
\hline \multirow[t]{4}{*}{$\begin{array}{l}\text { Verbal } \\
\text { Argument }\end{array}$} & $\begin{array}{l}\text { Warrant: Nuclear plants are being } \\
\text { installed only because it reduces the cost } \\
\text { but we can get more energy with solar } \\
\text { energy and wind panels in the long term. }\end{array}$ & Group students did not exist in class. \\
\hline & $\begin{array}{l}\text { Can radiation cause mutation in human } \\
\text { genes? } \\
\text { Claim: Radiation can cause mutations in } \\
\text { human genes. } \\
\text { Claim: One of the biggest triggers of } \\
\text { mutations in human genes is ultrasound. } \\
\text { Data: I can even explain with an } \\
\text { example; so, it is forbidden to enter the } \\
\text { x-ray rooms of the mothers carrying the } \\
\text { suspicion of pregnancy. }\end{array}$ & \\
\hline & $\begin{array}{l}\text { Claim: Mutations cause genetic } \\
\text { disorders, children with disabilities, } \\
\text { children with mental disabilities, } \\
\text { physical disorders. }\end{array}$ & \\
\hline & $\begin{array}{l}\text { Does a leak in nuclear power plants } \\
\text { always turn into a natural disaster? } \\
\text { Claim: A leak in nuclear power plants is }\end{array}$ & \\
\hline
\end{tabular}


always a natural disaster over time.

Warrant: Because, it is a nuclear waste, not a normal air, not water, a risky substance, is always transformed.

Can an explosion in a nuclear power plant spread all over the country? Warrant: It can spread very easily through the wind; through the rain...It can be spread very easily through weather events.

Backing: Abnormalities in children have been seen not only the area accident happened but also around the vicinity. Backing: The disaster in Chernobyl spread all over the Ukraine in that period. The effects still remain on human beings. Therefore, a phenomenon occurred at a certain place may influence nearby places.

Warrant: Absolutely, yes. Because there are so many gasses that deplete the ozone layer, and since forests after all cover a lot of space they are being destroyed. In this way, the natural environment of animals are also destroyed, thus it harms the animals.

Rebuttal: I do not think it harms the air directly. As a result, I know that water vapor or something come out of that plant. However, I know that the storage of nuclear materials, keeping them in a good way and their wastes do not dissolve easily in nature. I guess they were burying it in the ground, and this directly leads to soil pollution. This is the result of trees, such as birds, eating something from the ground. For example, birds are eating something from the ground .I think they are influenced thereby. I do not think it is directly in contact with the air.

\section{Written and Verbal Argument Analysis for Group D}

When the Figures 7 and 8 above were examined, it was observed that the frequency of use of the elements in the TAP decreased in written and verbal arguments. 

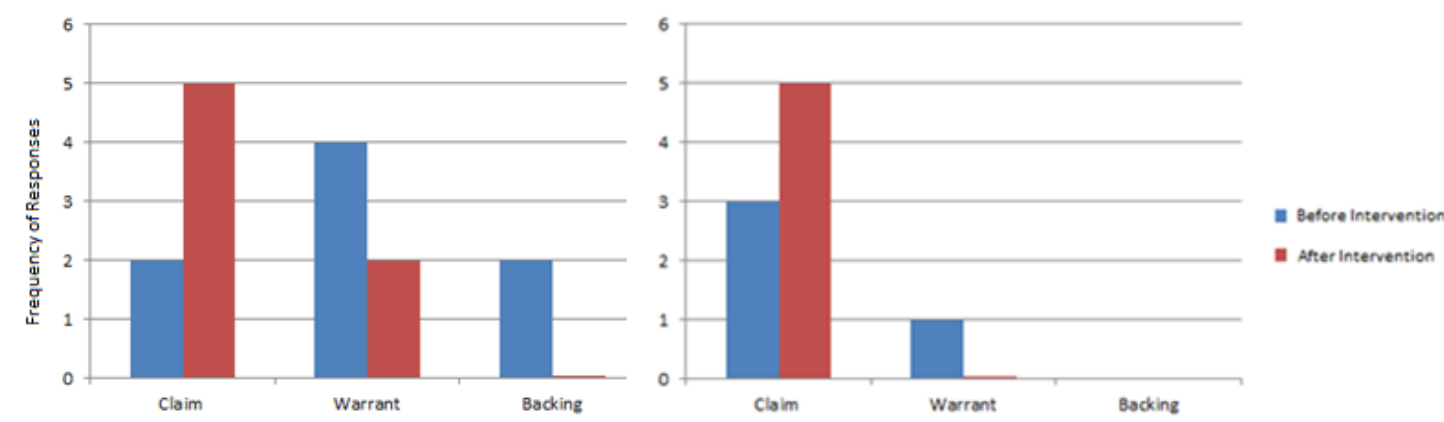

Figure 7. Written Argument Analysis for Group D

Figure 8. Verbal Argument Analysis for Group D

The detailed analysis of written and verbal arguments demonstrated that students mostly recommended use of sustainable energy resources as much as possible, such as wind energy, wave energy, solar energy, geothermal energy instead of nuclear energy. On the other hand, they had alternative ideas about nuclear power plants similar to other group of students. For example, they claimed that the gases released from the nuclear power plants are harmful and these gases cause ozone layer to be thinned and also increase global warming.

Table 4. Analysis of written and verbal arguments for Group D

\begin{tabular}{|c|c|c|}
\hline $\begin{array}{l}\text { Argument } \\
\text { type }\end{array}$ & Before Intervention & After Intervention \\
\hline Written & Supportive Comments/Pro-Arguments & Supportive Comments/Pro-Arguments \\
\hline Argument & We do not support. & - \\
\hline & $\begin{array}{l}\text { Unsupportive Comments } \\
\text { Warrant: Because, in our country the } \\
\text { resources of sustainable development } \\
\text { (wind, sun, wave, geothermal) are } \\
\text { enough to meet our energy needs. } \\
\text { Instead of establishing nuclear power } \\
\text { plants, natural energy sources that are } \\
\text { not harmful to nature and human health } \\
\text { should be used. } \\
\text { Claim(s):-Besides, fumes from nuclear } \\
\text { power plants cause the ozone layer to } \\
\text { be thinned. Therefore, global warming } \\
\text { is rising. } \\
\text {-In humans, diseases such as cancer and } \\
\text { asthma are increasing. } \\
\text {-It is also difficult to safely use the } \\
\text { nuclear power plant in our country. } \\
\text { Adequate measures against the } \\
\text { possibility of explosion must be taken. }\end{array}$ & $\begin{array}{l}\text { Unsupportive Comments } \\
\text { Claim(s): - It causes to increase global warming } \\
\text { and greenhouse. } \\
\text { - Nuclear plant explosion reduces the viability in } \\
\text { there. } \\
\text { - During the explosion of nuclear power plants, } \\
\text { pollutants usually spread around. } \\
\text { - Even filter need to be installed in the chimneys } \\
\text { of the factories, if it is not used in nuclear power } \\
\text { plants, it will give too much polluted gas to the air. } \\
\text { - In the case of a leak from nuclear power plants, } \\
\text { substances may be involved in soil. And, the } \\
\text { genetics of the grown plants deteriorate and can be } \\
\text { harmful to human health. }\end{array}$ \\
\hline $\begin{array}{l}\text { Verbal } \\
\text { Argument }\end{array}$ & $\begin{array}{l}\text { Warrant: We all do not support because } \\
\text { we think that sustainable energy } \\
\text { resources exist as much as possible, } \\
\text { such as wind energy, wave energy, solar } \\
\text { energy, geothermal energy, we think } \\
\text { that these will meet our energy needs. } \\
\text { We also think that nuclear power plants } \\
\text { will cause discomfort in people. } \\
\text { Moreover, you cannot get as much }\end{array}$ & $\begin{array}{l}\text { Claim: There are some aspects that I support. It } \\
\text { provides enormous energies. } \\
\text { Claim: It provides enormous energies and these } \\
\text { energies would really provide a good opportunity } \\
\text { for the development of the country when it is used } \\
\text { properly, but the factors mentioned in the table are } \\
\text { also effective. }\end{array}$ \\
\hline
\end{tabular}




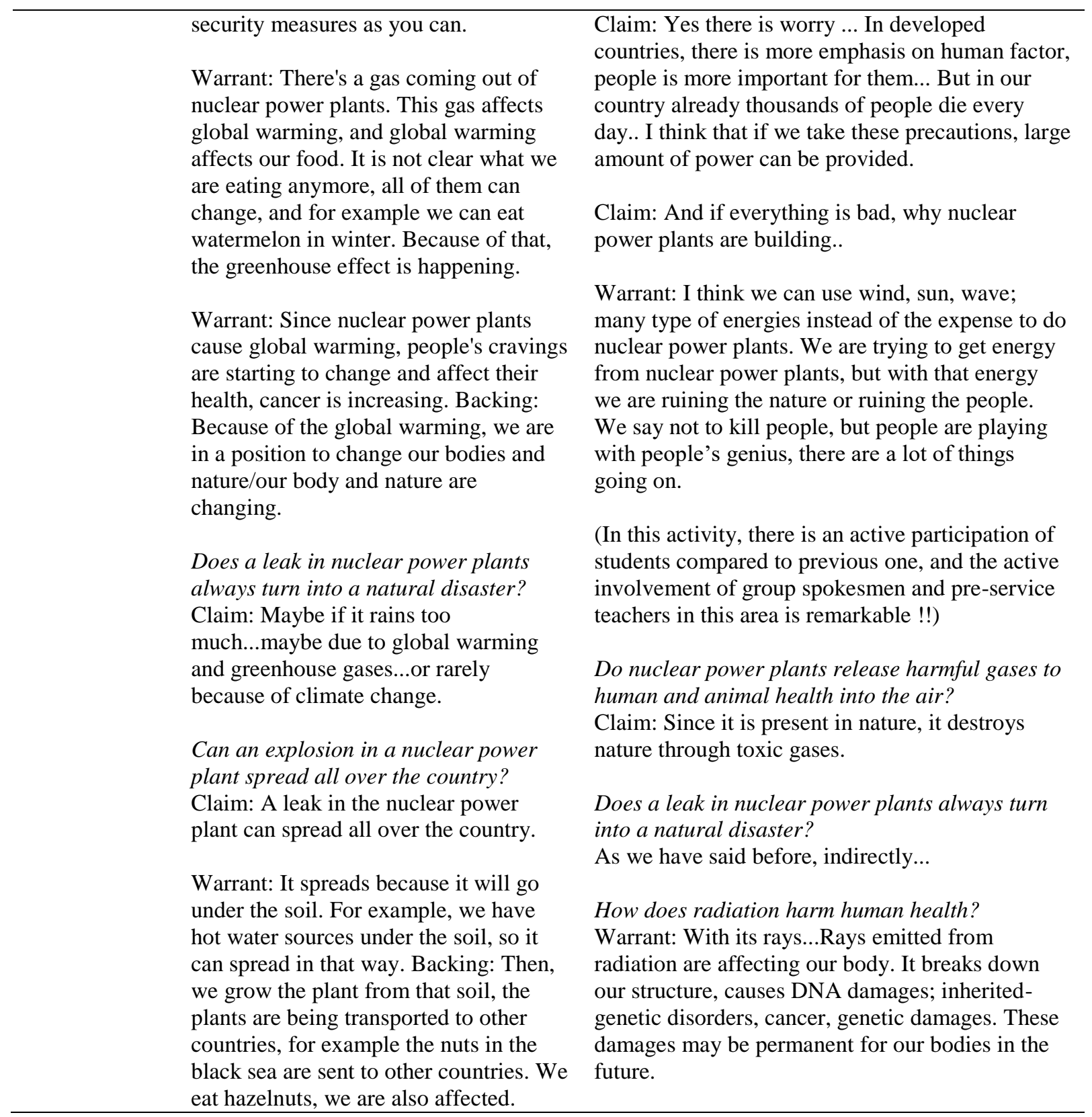

\section{DISCUSSION}

This study focused on pre-service science teachers' argument quality in the context of nuclear power plants. The topic of nuclear power plants, which everyone is familiar with, was chosen as the subject of the discussion. Venville and Dawson (2010) emphasized the importance of content knowledge in improving quality of the argument. The written and verbal argument analysis of preservice science teachers' indicated that teacher candidates lacked competency in developing scientific arguments in the context of nuclear power plants. The results showed that pre-service teachers mostly used warrant element in Toulmin Argument Pattern to justify their explanations both before and after the intervention. Erduran, Simon, and Osborne (2004) stated that rebuttals are an indispensable element of better quality arguments and they are also a sign of sustained engagement in the argumentation discourse. Martín-Gámez and Erduran (2018) also pointed out that pre-service science 
teachers should be to acquire awareness about the importance of rebuttals in an argument, not only to teach to their students to construct quality arguments, but also to encourage the engagement of learners in dialogical conversation. In the analysis of the written and verbal arguments of the current study, the numbers of rebuttals were very few. In addition, there was not an improvement in the frequency of the elements used in the TAP in all groups. In this sense, it may not appear to be an outstanding improvement in terms of the argument quality. Furthermore, especially verbal arguments of preservice students revealed that they have some alternative conceptions about nuclear power plants. For instance, some of the students believed that nuclear plants harm or pollute the air, that is; poisonous wastes or toxic gases are released into the air from nuclear plants. Even some of them considered that released gases from these plants trigger or increase global warming. Similarly, another common idea was that nuclear power plants would not only pollute the air but also contaminate the soil through weather events such as wind and rain. Besides, almost all of them agreed on that radioactive energy harms nature and living organisms. While they claim that radiation can cause mutations and mutations can cause genetic disorders, children with disabilities, children with mental disabilities, physical disorders and etc., they could not scientifically explain how radiation causes all these mutations in living organisms. One of the common beliefs among them was that an explosion in the nuclear power plant would spread to the whole country. The main cause of this idea was the Chernobyl nuclear accident, which students give a lot of examples during discussions. It is seen that this incident in the real life deeply influenced students' thoughts against nuclear power plants. When the subject was radiation, the examples were usually related to Chernobyl, Hiroshima and Nagasaki. In addition to these, they insisted on that safety/security measures would not be taken sufficiently in their country of residence. The results of this study were consistent with the findings of Aydeniz and Gürçay (2013) in which the written arguments were analyzed in the context of nuclear power plants. They stated that students make a direct link between the nuclear power plants and the natural disaster without discussing the causes of the leak. In Aydeniz and Gürçay's (2013) study students could not discuss why a possible leak may cause a natural disaster from a scientific perspective. Moreover, they claimed that nuclear power plants release some hazardous gases to the air, causing several detrimental effects on human and animal life.

There are many reasons that students have difficulty in constructing arguments and participating in argumentative discourse. One of the reasons that students' lack of opportunity to engage in such activities within current pedagogical practices (insufficient participation) and the other is teachers' limited pedagogical skills to manage argumentation and discussion sessions in classrooms (Driver et al. 2000).

This study was useful for introducing the Toulmin Argument Pattern to the students. They had the opportunity to present their ideas on a socio-scientific topic. In this process, they conducted group work and exchanged ideas between the groups and within the groups. Thus, a social environment was 
created to share ideas and thoughts. According to Driver et al. (2000), students' involvement in argumentation discourse promotes conceptual understanding in science. Erduran and JiménezAleixandre (2008) pointed out that argument has both an individual and a social meaning. Social argumentation called as internal argumentation is a powerful tool for improving high-level thinking. They stated that 'social dialogue offers a way to externalize internal thinking strategies embedded in argumentation' (Erduran and Jiménez-Aleixandre, 2008, p.12).

Although there has been growing interest to the argumentation in science education (Aydeniz et al., 2012; Cetin et al. 2016; Özdem et al. 2017), there are limited studies about pre-service science teachers' argumentation skills (Martín-Gámez \& Erduran, 2018). Considering the need for studies in the field of pre-service teachers' understanding of argumentation, this study merits discussion. Argumentation can be explicitly taught in teacher education besides elementary and secondary education and pre-service teachers should be encouraged to use the discourse of argumentation in their science classrooms.

\section{Acknowledgement and Funding}

The author disclosed receipt of the following financial support for the research, authorship, and/or publication of this article: This research was supported by the Scientific and Technological Research Council of Turkey (TUBITAK) in frame of 2218 Domestic Postgraduate Scholarship Program Scholarship. In addition, this study was presented as a conference paper in the following congress: Yalçınkaya-Önder, E., \& Pekmez, E. (2017). Argümantasyon ve Nükleer Santraller. IVth International Eurasian Educational Research Congress (EJER), Denizli, Türkiye.

\section{REFERENCES}

Aydeniz, M., \& Dogan, A. (2016). Exploring the impact of argumentation on pre-service science teachers' conceptual understanding of chemical equilibrium. Chemistry Education Research and Practice, 17(1), 111-119.

Aydeniz, M., \& Gürçay, D. (2013) Assessing quality of pre-service physics teachers' written arguments. Research in Science \& Technological Education, 31(3), 269-287.

Aydeniz, M., Pabuccu, A., Cetin, P. S., \& Kaya, E. (2012). Impact of argumentation on college students' conceptual understanding of properties and behaviors of gases. International Journal of Science and Mathematics Education, 10, 1303-1324.

Berland, L. K., \& McNeill, K. L. (2009). Using a learning progression to inform scientific argumentation in talk and writing. Learning Progression in Science.

Berland, L.K., \& Hammer, D. (2012). Framing for Scientific Argumentation. Journal of Research in Science Teaching, 48(1), 68-94.

Cetin, P. S. (2014). Explicit argumentation instruction to facilitate conceptual understanding and argumentation skills. Research in Science \& Technological Education, 32(1), 1-20.

Cetin, P. S., Metin, D., Capkinoglu, E., \& Leblebicioglu, G. (2016). Seeking the Trace of Argumentation in Turkish Science Curriculum. Science Education International, 27(4), 570-591. 
Çınar, D. \& Bayraktar, S. (2014). Evaluation of the effects of argumentation based science teaching on 5th grade students' conceptual understanding of the subjects related to "matter and change". International Journal of Education in Mathematics, Science and Technology, 2(1), 49-77.

Driver, R., Newton, P., \& Osborne, J. (2000). Establishing the norms of scientific argumentation in classrooms. Science education, 84(3), 287-312.

Duschl, R., \& Osborne, J. (2002). Supporting and promoting Argumentation Discourse in Science Education. Studies in Science Education, 38, 39-72.

Erduran, S., \& Jiménez-Aleixandre, M. P. (2008). Argumentation in science education. Perspectives from classroom-Based Research. Dordre-cht: Springer.

Erduran, S., Simon, S., \& Osborne, J. (2004). TAPping into argumentation: Developments in the application of Toulmin's argument pattern for studying science discourse. Science Education, 88(6), 915-933.

Hsu, C.-C., Chiu, C.-H., Lin, C.-H., \& Wang, T.-T. (2015). Enhancing skill in constructing scientific explanations using a structured argumentation scaffold in scientific inquiry. Computers \& Education, 91, 46-59.

Kaya, E. (2013). Argumentation Practices in Classroom: Pre-service teachers' conceptual understanding of chemical equilibrium. International Journal of Science Education, 35(7), 1139-1158.

Martín-Gámez, C., \& Erduran, S. (2018).Understanding argumentation about socio-scientific issues on energy: a quantitative study with primary pre-service teachers in Spain. Research in Science \& Technological Education, 36(4), 463-483.

Muratsua, K., Inagakib, S., Yamaguchic, E., Yamamotod, T., Sakamotoe, M., \& Kamiyamaf, S. (2015). An Evaluation of Japanese Elementary Students' Understanding of the Criteria for Rebuttals in Argumentation. Procedia - Social and Behavioral Sciences, 167, 91-95.

Nussbaum, E. M. (2011). Argumentation, dialogue theory, and probability modeling: Alternative frameworks for argumentation research in education. Educational Psychologist, 46(2), 84-106.

Özdem, Y., Cakiroglu, J., Ertepinar, H., \& Erduran. S. (2013). The Nature of Pre-Service Science Teachers' Argumentation in Inquiry-Oriented Laboratory Context. International Journal of Science Education, 35(15), 2559-2586.

Özdem-Yilmaz, Y., Cakiroglu, J., Ertepinar , H., \& Erduran, S. (2017). The pedagogy of argumentation in science education: science teachers' instructional practices. International Journal of Science Education, 39(11), 1443-1464.

Sampson, V., \& Blanchard, M. R. (2012). Science teachers and scientific argumentation: Trends in views and practice. Journal of Research in Science Teaching, 49(9), 1122-1148.

Sandoval, W. A., \& Millwood, K. (2005). The quality of students' use of evidence in written scientific explanations. Cognition and Instruction, 23(1), 23-55.

Şimşek, H., \& Yıldırım, A. (2011). Sosyal bilimlerde nitel araştırma yöntemleri. Ankara: Seçkin Yayıncılık.

Toulmin, S. (1958). The uses of argument. Cambridge: Cambridge University Press.

Toulmin, S. (2003). The uses of argument (Updated ed.). New York: Cambridge University Press. 
Uluçınar-Sağır, Ş. \& Kılıç, Z. (2013). İlköğretim öğrencilerinin bilimin doğasını anlama düzeylerine bilimsel tartı̧̧ma odaklı öğretimin etkisi. Hacettepe Üniversitesi Eğitim Fakültesi Dergisi, 44, 308318.

Venville, G. J., \& Dawson, V. M. (2010). The impact of a classroom intervention on grade 10 students' argumentation skills, informal reasoning, and conceptual understanding of science. Journal of Research in Science Teaching, 47(8), 952-977.

Von Aufschnaiter, C., Erduran,S., Osborne, J., \& Simon, S. (2008). Arguing to Learn and Learning to Argue: Case Studies of How Students' Argumentation Relates to Their Scientific Knowledge. Journal of Research in Science Teaching, 45(1), 101-131.

Wu, H. K., \& Hsieh, C. E. (2006). Developing sixth graders' inquiry skills to construct explanations in inquiry-based learning environments. International Journal of Science Education, 28(11), 12891313.

Yıldırım, A. (1999). Nitel araştırma yöntemlerinin temel özellikleri ve eğitim araştırmalarındaki yeri ve önemi. Eğitim ve Bilim, 23(112), 7-17.

Yalçınkaya-Önder, E., \& Pekmez, E. (2017). Argümantasyon ve Nükleer Santraller. IVth International Eurasian Educational Research Congress (EJER), Denizli, Türkiye.

Zembal-Saul, C., Munford, D., Crawford, B., Friedrichsen, P., \& Land, S. (2002). Scaffolding Pre-service Science Teachers' Evidence-Based Arguments during an Investigation of Natural Selection. Research in Science Education, 32, 437-463.

Zohar, A., \& Nemet, F. (2002). Fostering students' knowledge and argumentation skills through dilemmas in human genetics. Journal of Research in Science Teaching, 39(1), 35-62. 


\section{UZUN ÖZET}

\section{Giriş}

Argümantasyon konusunda yapılan çalışmalar incelendiğinde, ortaokul ve lise öğrencilerinin bile gerekçe ve destekleme gibi argümantasyon unsurlarını kullanamadıkları görülmektedir (Sandoval ve Millwood, 2005). Martín-Gámez ve Erduran (2018), öğretmen adaylarının argümanları anlamada zorluk çektiklerini belirtmişlerdir. Ayrıca, adayların gerekçelerin bilimsel argümandaki rolü ve anlamını anlamadıklarını ve farklı stratejilerinin kullanımının tartışmalar, münazaralar ve deneylerle sınırlı kaldığını ifade etmişlerdir. Bunlara ek olarak, katılımcıların yaş aralığı ve öğretmenlik deneyimi süresinin argümantasyon anlayışlarının kalitesini etkilemediğini saptamışlardır. Ayrıca, öğretmen adaylarının argümantasyon konusunda daha sağlam ve uzun oturumlara katılırlarsa yarar sağlama ihtimallerinin daha yüksek olacağını da ifade etmişlerdir. Yapılan çalışmalar 1şığında, bu çalışmanın temel amacı, öğretmen adaylarının nükleer santraller konusunda geliştirdikleri argümanların kalitesini belirlemek ve Toulmin Argüman Modelindeki unsurların bu konu bağlamında kullanılma sıklığını belirlemektir.

\section{Metot}

$\mathrm{Bu}$ çalışma Toulmin Argüman Modeli temel alınarak yürütülmüş nitel bir çalışmadır ve öğretmen adaylarının Toulmin Argüman Modeli’ndeki unsurları kullanma sıklıklarını nükleer santraller konusu kapsamında incelemektedir. Çalışma grubunu bir devlet üniversitesinde Fen Bilgisi Öğretmenliği programında okuyan 48 öğretmen adayı oluşturmaktadır. Çalışma grubunu oluşturmak için kolay ulaşılabilir örnekleme yöntemi kullanılmıştır.

$\mathrm{Bu}$ çalışma grubunu oluşturan öğretmen adayları örgün eğitim programlarında mevcut çalışma öncesinde argümantasyon konusuna ilişkin bir kurs ya da eğitim almamıştır. Öğretmen adaylarına eğitim verilmeden önce adaylardan rastgele öğrenci grupları oluşturmaları istenmiştir ve öğrencilere ülkelerinde veya yaşadıkları şehirde nükleer santral kurulmasını destekleyip desteklemedikleri sorusu sorularak bir tartışma başlatılmıştır. Ek olarak, Aydeniz ve Gürçay'ın (2013) çalışmasında nükleer santraller konusunda yanıt alınamayan sorular öğrencilere yöneltilmiştir. Grup içi ve gruplar arası bilimsel tartışmalar yazılı ve sözlü olarak analiz edilmek üzere video kaydı altına alınmıştır. Nükleer santraller etkinliğiyle birlikte beş etkinlik daha uygulanmıştır ancak bu çalışmada diğer etkinliklerin analizine yer verilmemiştir. Ardından, öğretmen adayları çalışmanın araştırmacılarından biri tarafından Toulmin Argüman Modeli ve argümantasyon hakkında yaklaşık iki buçuk saat kadar süren bir eğitim almışlardır. Eğitim süresince, öğretmen adaylarıyla argüman ve argümantasyon kavramlarıyla ilgili bilimsel tanımlar paylaşılmıştır. Ayrıca, çeşitli konularda ilgili literatürden argüman örnekleri öğrencilerin diline çevrilerek sunulmuş ve iyi bir argümanda olması gereken özellikler vurgulanmıştır. Bu eğitim sonrasında, aynı etkinlikler bu modelin unsurları göz önüne 
bulundurularak tekrarlanarak yine kayıt altına alınmıştır. Etkinlik boyunca öğretmen adayları gruplara katılma ve birbirleriyle fikir alışverişinde bulunma fırsatı bulmuşlardır.

\section{Sonuç ve Tartışma}

$\mathrm{Bu}$ çalışma, öğretmen adaylarının nükleer santraller konusundaki argüman kalitesini ölçemeye odaklanmıştır. Bilimsel tartışma konusu olan nükleer santraller hemen herkesin olumlu ya da olumsuz düşünceye sahip olduğu sosyo-bilimsel konulardan biridir. Venville ve Dawson (2010) da argüman kalitesinin iyileştirilmesinde içerik bilgisinin önemini vurgulamıştır. Fen bilgisi öğretmen adaylarının yazılı ve sözlü argüman analizi öğretmen adaylarının nükleer santraller konusunda bilimsel argümanlar geliştirme konusunda yetkin olmadıklarını göstermiştir. Araştırmanın sonuçları öğretmen adaylarının hem uygulama öncesinde hem de uygulama sonrasında argümanlarını haklı çıkarmak için Toulmin Argüman Modelinde çoğunlukla gerekçe unsurunu kullandıklarını göstermiştir. Erduran, Simon ve Osborne (2004), Toulmin Argüman Modelindeki çürütücülerin iyi kalite argümanlarının vazgeçilmez bir unsuru olduğunu ve aynı zamanda argümantasyon söyleminde sürekli katılımın bir işareti olduğunu belirtmişlerdir. Martín-Gámez ve Erduran (2018) öğretmen adaylarının, sadece kaliteli argümanlar inşa etmeyi öğretmekle kalmayıp aynı zamanda öğrencilerin diyaloglu konuşmalara katılımını teşvik etmek için tartışmada çürütücülerin önemi konusunda farkındalık kazanmaları gerektiğini de belirtmiştir. Mevcut çalışmanın yazılı ve sözlü argümanların analizinde çürütücü sayısının azlığı dikkat çekmiştir. Ayrıca, Toulmin Argüman Modelindeki unsurların kullanım frekansında tüm gruplar için büyük bir gelişme olmamıştır. Ayrıca, öğretmen adaylarının özellikle sözlü argümanların analizi nükleer santraller hakkında bazı alternatif fikirlere sahip olduklarını ortaya koymuştur. Örneğin, öğrencilerin bir kısmı nükleer santrallerin havaya zararlı gazlar saldığını ve havayı kirlettiğine inanmaktadır. Hatta bazıları bu tesislerden salınan gazların küresel 1sınmayı tetiklediğini veya artırdığı fikrine sahiptir. Benzer şekilde, bir başka yaygın fikir nükleer santrallerin yalnızca havayı kirletmekle kalmayacağı aynı zamanda toprağı rüzgâr ve yağmur gibi hava olaylarıyla doğayı kirleteceği yönündedir. Ayrıca, öğrencilerin büyük çoğunluğu radyoaktif enerjinin doğaya ve canlılara zarar verdiği konusunda hemfikirdir. Radyasyonun mutasyonlara neden olabileceğini ve mutasyonların da genetik bozukluklara, çocukların zihinsel ya da fiziksel engelli doğmalarına neden olabileceğini iddia etmelerine rağmen, tüm bu mutasyonların canlı organizmalara nasıl gerçekleştiğini bilimsel olarak açıklayamamışlardır. Öğretmen adaylarındaki ortak inançlardan biri de nükleer santraldeki bir patlamanın tüm ülkeye yayılacağı fikridir. $\mathrm{Bu}$ fikrin ana nedeni, öğrencilerin tartışmalar sırasında sıklıkla örnek verdikleri Çernobil nükleer kazasıdır. Gerçek hayattaki bu olayın öğrencilerin nükleer santrallere yönelik düşüncelerini derinden etkilediği de tespit edilmiştir. Bunlara ek olarak, ikamet ettikleri ülkede emniyet/güvenlik önlemlerinin yeterince alınmayacağı konusunda 1srarcı olmuşlardır. Bu çalışmanın sonuçları, yazılı argümanların nükleer santraller bağlamında analiz edildiği Aydeniz ve Gürçay (2013) 'un bulgularıyla uyumludur. Öğretmen adayları nükleer santrallerdeki sızıntının sebeplerini tartışmadan nükleer santrallerle doğal afet arasında doğrudan bir 
bağlantı kurduklarını ifade etmişlerdir. Ayrıca, muhtemel bir sızıntının neden doğal bir felakete neden olabileceğini bilimsel bir bakış açısıyla tartışamamışlardır. Nükleer santrallerin havaya bazı tehlikeli gazlar saldığını ve insan ve hayvan yaşamı üzerinde çeşitli zararlı etkilere neden olduğunu da iddia etmişlerdir (Aydeniz ve Gürçay, 2013).

Öğrencilerin argüman oluşturmada ve tartışmaya açık söylemlere katılmada zorluk çekmesinin birçok nedeni vardır. Öğrencilerin mevcut pedagojik uygulamalarda bu tür etkinliklere katılma şansının olmayışının nedenlerden biri (yetersiz katılım) ve diğeri ise öğretmenlerin sınıflardaki tartışma ve tartışma oturumlarını yönetme konusundaki sınırlı pedagojik becerileridir (Driver ve ark. 2000). Bu çalışma, öğrencilere Toulmin Argüman Modelini tanıtmak için faydalı olmuştur. Öğretmen adayları düşüncelerini sosyo-bilimsel bir konuda sunma firsatını bulmuşlardır. Bu süreçte grup çalışması yapmış ve gruplar arasında ve gruplar içinde fikir alışverişinde bulunmuşlardır. Böylece fikir ve düşünceleri paylaşmak için sosyal bir ortam yaratılmıştır. Driver ve ark. (2000) öğrencilerin bilimsel tartışmalara katılımlarının bilimde kavramsal anlayışı desteklediğini ifade etmişlerdir. Erduran ve Jiménez-Aleixandre (2008), bilimsel tartışmanın (argümantasyonun) hem bireysel hem de sosyal bir anlamı olduğunu belirtmiştir. İçsel argümantasyon olarak adlandırılan sosyal tartışmanın üst düzey düşünmeyi geliştirmek için güçlü bir araç olduğunu ifade etmişlerdir.

Fen eğitiminde argümantasyona olan ilginin giderek artmasına rağmen (Aydeniz ve ark., 2012; Cetin ve ark. 2016; Özdem ve ark. 2017), öğretmen adaylarının bilimsel tartışma becerilerine ilişkin sınırlı sayıda çalışma vardır (Martín-Gámez ve Erduran, 2018). Öğretmen adaylarıyla ilgili olarak argümantasyon alanındaki çalışmalara ihtiyaç duyulduğu dikkate alındığında bu çalışma ilgili alana katk1 sunacaktır. 